\title{
The effects of the conditioned medium of fetal neural cell culture on the apoptosis in the rat brain after traumatic brain injury
}

\author{
Lisyany M..$^{1}$, Govbakh I. ${ }^{2}$, Belska L. ${ }^{1}$, Tsupykov O., ${ }^{3,4}$, Palamarova A. ${ }^{1}$ \\ ${ }^{1}$ Romodanov State Institute of Neurosurgery, National Academy of Medical Sciences of Ukraine, Kyiv, Ukraine \\ ${ }^{2}$ Kharkiv Medical Academy of Postgraduate Education, Ministry of Public Health of Ukraine, Kharkiv, Ukraine \\ ${ }^{3}$ Bogomoletz Institute of Physiology, National Academy of Sciences, Kyiv, Ukraine \\ ${ }^{4}$ State Institute of Genetic and Regenerative Medicine, National Academy of Medical Sciences of Ukraine, Kyiv, Ukraine \\ Corresponding author’s e-mail: nimun.neuro@gmail.com
}

\section{ABSTRACT}

A promising treatment method of the traumatic brain injury (TBI) may be stem cell therapy. However, the question of the nature and mechanisms of action of humoral factors produced by stem cells on apoptotic and reparative processes in the brain after trauma remains open.

The PURPOSE of the study was to research the effect of conditioned media of fetal neural cell cultures on the number of apoptotic cells in the cortex and subcortical structures of the rat brain after TBI.

MATERIALS AND METHODS. TBI was modelled by dropping a metal cylinder on rat's head. Rat fetuses (E17-18) brain was used to obtain cultures of neural stem/progenitor cells. Conditioned media from cell cultures with high adhesive properties (HA-CM) and low adhesive properties (LA-CM) were used to treat the experimental TBI in rats. The presence of p53-positive cells in the cortex and subcortical structures was investigated by immunohistochemistry.

RESULTS. Immunohistochemical analysis of brain sections showed that on the $5^{\text {th }}$ day after TBI in rats there was an increase in the number of p53-positive cells in both the cortex and subcortical structures of the brain. The injection of HA-CM and LA-CM to animals on the $2^{\text {nd }}$, $3^{\text {rd }}$, $4^{\text {th }}$ days after TBI was found to reduce the number of p53-positive cells in the cortex, hippocampus and thalamus by approximately half compared to the TBI group. A significant difference in the inhibitory effect of two different conditioned media (HA-CM and LA-CM) on apoptosis in the brain of rats after $T B I$ was not detected.

CONCLUSIONS. The administration of conditioned media of rat fetal neural cell cultures caused a significant decrease in the number of p53positive cells in both the cortex and subcortical structures on the $5^{\text {th }}$ day after the brain injury.

KEY WORDS: traumatic brain injury; fetal neural cells culture; conditioned media; apoptosis; p53

A promising strategy of the treatment of the traumatic brain injury (TBI) can be stem cell therapy. Transplanted stem cells after TBI have different effects on damaged neural tissue: interact with intact brain cells, reduce the expression of molecules that inhibit axon growth, produce factors promoting neural plasticity that increase the growth of neuritis, contribute to the restoration of neurological functions [1-4].

The possibility that the therapeutic effect after stem cell transplantation is due only to the replacement of damaged neural tissue is extremely unlikely, because only a small number of transplanted cells survive [2]. For example, transplanted multipotent mesenchymal stromal/stem cells (MMSCs) secrete factors that through a paracrine effect or intercellular interaction can induce proliferation of the endogenous stem cells in the brain and stimulate the recipient's neural cells to secrete biologically active factors and thus improve functional recovery after an injury $[3,5]$.

There is much evidence that after $\mathrm{TBI}$, a programmed death of neurons and other neural cells develop in the brain [6-8]. Such programmed cell death is accompanied by caspase activation, DNA fragmentation, release of cytochrome $\mathrm{C}$ from mitochondria, cytoskeleton disintegration and formation of apoptotic cells and many other cell dysfunctions [6-8]. It should be noted that such apoptotic changes are observed not only in different models of TBI in animals, but also during head injury in human [9].

Apoptosis of brain neural cells after trauma depends on the location and time of the study after the injury. Thus, in the cerebral cortex after trauma apoptotic cells were detected in an hour and their maximum 
accumulation was observed after 24 hours with a gradual decrease by the end of the first week. In white matter and in the subcortical structures of the brain (hippocampus and thalamus) such cells were detected in 12 hours after the injury, and their highest content was one week later [10]. The peculiarity of apoptosis after TBI is that apoptotic cells are found not only among neurons but also glial cells, namely oligodenrocytes and microglia cells, which can be localized in both the cortex and subcortical structures of the brain.

One of the markers of apoptosis is the transcription factor p53, which is an indicator of not only the presence of a tumor in the body, but also the development of apoptosis in neural cells, a sign of neurodegeneration and modulation of glial cell activity $[9,11]$. The mechanism of p53 action can be released by various molecular pathways, which have not been fully studied yet. After TBI in the cortex and hippocampus, there is an increase in the amount of mRNA and p53 protein. Inhibition of p53 production by various factors leads to a decrease in the manifestations of apoptosis and reduced death of neurons and astrocytes $[12,13]$.

The question of the number and localization of p53-positive apoptotic cells in the cortex and subcortical structures of the brain after TBI remains open. The increased number of apoptotic cells in these structures persists for several months, indicating long-term changes in the brain after an injury and the need to find treatments and prevent the development of both primary and secondary apoptosis after TBI [10]. On the other hand, questions about the nature and mechanisms of action of humoral factors produced by stem cells on pathological processes in the brain, including apoptosis and reparation after trauma, are still insufficiently studied [2, 3, 14].

The PURPOSE of the study was to examine the effect of conditioned media of rat fetal neural cell cultures on the number of apoptotic cells in the cortex and subcortical structures of the brain in rats after traumatic brain injury.

\section{MATERIALS AND METHODS}

Outbred sexually mature male and female rats, aged 4-5 weeks, weighing $140-160 \mathrm{~g}(\mathrm{n}=37)$ from the vivarium of the A. P. Romodanov State Institute of Neurosurgery NAMS of Ukraine were used in the study. All work with experimental animals was carried out in compliance with legal norms and requirements of the Law of Ukraine No.3447 IV "On the protection of animals from cruelty", "European Convention for the protection of vertebrate animals used for research and other scientific purposes" (Strasbourg, 1986), taking into account the principles of bioethics and biosafety standards. The study was approved by the Commission on Ethics and Bioethics of the A. P. Romodanov State Institute of Neurosurgery NAMS of Ukraine (No. 26 dated 11.05.2018). Animals were kept under standard conditions of the vivarium with free access to food and water ad libitum. Euthanasia of experimental animals was performed by the overdose of ether anesthesia.

Modeling of TBI in rats. Traumatic brain injury in rats was modeled according to the method of Romanova G. and Biloshitsky V. [15, 16]. Before simulating $\mathrm{TBI}$, rats were anesthetized intraperitoneally with $0.5 \mathrm{~mL}$ of the mixture of Ketamine $(70.0 \mathrm{mg} / \mathrm{kg})$ and Sedazine $(15 \mathrm{mg} / \mathrm{kg})$. Traumatic brain injury was simulated by dropping a metal cylinder (weighing $100 \mathrm{~g}$ ) from the height of $120 \mathrm{~cm}$ on rat's head. Animal's head was placed on a $5 \mathrm{~cm}$ high foam pad under a $120 \mathrm{~cm}$ high and $2.5 \mathrm{~cm}$ diameter plastic vertical tube so that the metal cylinder struck the left hemisphere in the frontal and parietal areas of the brain. After the injury, the rats hold breath reflexively for a few seconds, as well as there appeared minor seizures in the lower limbs and a tail lift within 5-10 seconds. After 20-30 minutes the animals came out of anesthesia and began to move and returned to their cage.

Obtaining and culturing fetal neural cells of rats. Anesthetized pregnant female rats $(n=14)$ at $17-18$ day of gestation (E17-18) were euthanized by cervical dislocation. Under sterile conditions, the brains were isolated from 4-6 fetuses, washed in DMEM medium (Sigma-Aldrich, USA), blood vessels and meninges were removed, transferred to fresh nutrient medium and mechanically dissociated by pipetting [17]. The resulting cell suspensions were pelleted by centrifugation for 5 min at $1500 \mathrm{rpm}$, washed in DMEM medium. The cell pellet was resuspended in fresh DMEM medium and the number and viability of the cells were counted using $0.1 \%$ solution of Trypan blue. The cells were seeded into plastic $50 \mathrm{~mm}$ Petri dishes (Sarstedt, USA) at concentration of $4 \cdot 10^{6}$ cells per dish in $5.0 \mathrm{~mL}$ of DMEM culture medium supplemented with $10 \%$ fetal calf serum (Sigma, USA) and $80 \mu \mathrm{g} / \mathrm{mL}$ gentamycin (Farmacia, Ukraine). Cells were cultured in a $\mathrm{CO}_{2}$ incubator (Nuve, Turkey) with $5 \% \mathrm{CO}_{2}$ at $+37{ }^{\circ} \mathrm{C}$ and $95 \%$ humidity. After 24 hours of incubation, the cell cultures were divided into 2 groups. The cells with low adhesion were aspirated in a separate tube, pelleted by centrifugation. The pellet was resuspended in fresh DMEM medium and $4 \cdot 10^{6}$ cells transferred to new Petri dish, and cultured in $5.0 \mathrm{~mL}$ DMEM medium with antibiotics, but without fetal calf serum in a $\mathrm{CO}_{2}$ incubator for 48 hours. The second part of the cells that adhered to the plastic (cells with high adhesive properties), were further cultured in $5.0 \mathrm{~mL}$ fresh DMEM medium without fetal calf serum in a $\mathrm{CO}_{2}$ incubator for 48 hours. The analysis of cell cultures with microphoto registration was performed twice a day during the entire time of cultivation using an inverted microscope TS-100 (Nikon, Japan).

After culturing, conditioned media were aspirated from cell cultures with high adhesive properties (HA-CM) and low adhesive properties (LA-CM). The collected medium was centrifuged at $3000 \mathrm{rpm}$ for 10 minutes, the protein level was determined and samples for $2.0 \mathrm{~mL}$ per cryovial frozen at $-20^{\circ} \mathrm{C}$. In both types of conditioned medium the protein content was determined at a wavelength of $260 \mathrm{~nm}$ and $280 \mathrm{~nm}$ using a spectrophotometer SF-24 (Lomo, Russia). HA-CM was found to contain $0.28 \mathrm{mg} / \mathrm{mL}$ protein and LA-CM $-0.26 \mathrm{mg} / \mathrm{mL}$ protein.

Thawed conditioned media were used to treat the experimental TBI in rats. Conditioned media was administered by $1 \mathrm{~mL}$ to animals on the $2^{\text {nd }}, 3^{\text {rd }}, 4^{\text {th }}$ day after the injury by intramuscular injection. Animals were randomly divided into 4 groups: group $1(n=5)$ - intact animals, which did not undergo any experimental treatment; group $2(n=6)$ - animals with $\mathrm{TBI}$, which were administered with $1.0 \mathrm{~mL}$ of DMEM medium (comparison group); group $3(n=6)$ - animals with TBI, which were treated with LA-CM; group $4(n=6)$ - animals with TBI, which were treated with HA-CM. On the $5^{\text {th }}$ day after TBI, the animals were euthanized by cervical dislocation under ether anesthesia and the brain was isolated for immunohistochemical examination.

Immunohistochemical analysis of brain sections. The brain was fixed in $4 \%$ formaldehyde and embedded into paraffin blocks according to conventional histological techniques. 4-6 $\mathrm{mm}$ sections were prepared using microtome Microm HM-430 (Thermo Fisher Scientific, USA).
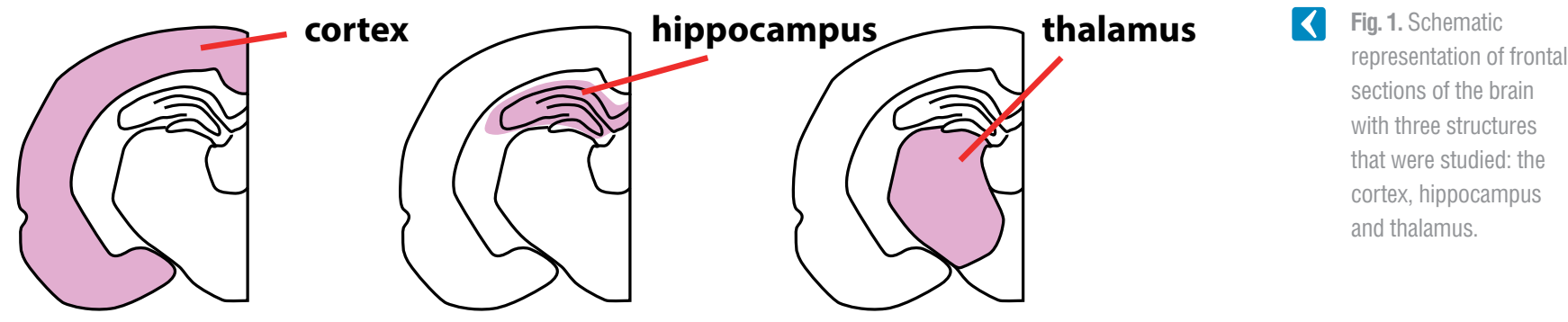
The sections were placed on HistoBond ${ }^{{ }}+\mathrm{M}$ adhesive slides (Marienfeld, Germany) for further immunohistochemical staining. The restoration of antigenicity was performed for 40 minutes at $98^{\circ} \mathrm{C}$ in the DAKO PT Module in High pH buffer (Dako Omnis, Denmark). The brain sections were incubated with primary mouse monoclonal anti-p53 antibodies at dilution 1:500 (clone D0-7, DAKO, Denmark) for 30 minutes at room temperature. After washing the sections in buffer, the primary antibodies were visualized using DAKO Flex+ detection system (DAKO, Denmark). Sections were stained with diaminobenzidine for 3 minutes and then contrasted with Mayer's hematoxylin (BioGnost, Croatia). Stained sections were mounted with Histofluid medium (Marienfeld, Germany).

Counting of p53-positive cells. The number of p53-positive cells was counted in 5 representative fields of view in every fifth frontal section of the brain area: cortex (including parietal and pear-shaped zones), hippocampus (including CA1, CA3, hilus and dentate gyrus) and thalamus (Fig. 1). A total of 5 sections per animal were examined. An Axiolmager A2 microscope (Carl Zeiss, Germany) and an AxioCam MRc5 camera (Carl Zeiss, Germany) with a magnification of $\times 800$ were used for the analysis.

Statistical analysis. To compare the data of the experimental groups, the analysis of variance ANOVA was performed using Origin Pro 8.5 software (Origin Lab. Corp., USA). The difference was considered significant at $p \leq 0.05$. The total number of $p 53$-positive cells is presented as mean \pm standard error of the mean (SEM).

\section{RESULTS AND DISCUSSION}

The immunohistochemical analysis of brain sections using anti-p53 antibodies showed that in animals of the intact group (group 1) the number of p53-positive cells in 5 fields of view of the section was $8.7 \pm 1.5$ in the cortex, $4.5 \pm 1.4$ in the hippocampus, $5.1 \pm 1.9$ in the thalamus (Fig. 1). These results indicate approximately the same content of apoptotic cells in the cortex and subcortical structures of the brain.

On the $5^{\text {th }}$ day after the experimental traumatic brain injury in rats group two there was an increase in the number of p53-labeled cells in the cortex (Fig. 3) and subcortical structures of the brain. The number of p53-positive cells increased significantly in the cerebral cortex up to $518.5 \pm 12.7$ cells (Fig. 2). In the subcortical structures of the brain, namely, there was a significantly lower number of p53-positive cells (in the hippocampus $-112.6 \pm 4.7$, and in the thalamus $-82.4 \pm 3.2$ ) than in the cerebral cortex, but probably higher compared to the group of intact animals $(\mathrm{p}<0.05)$ (Fig. 2).

It was found that the administration of LA-CM and HA-CM in animals with traumatic brain injury reduced the number of p53-positive

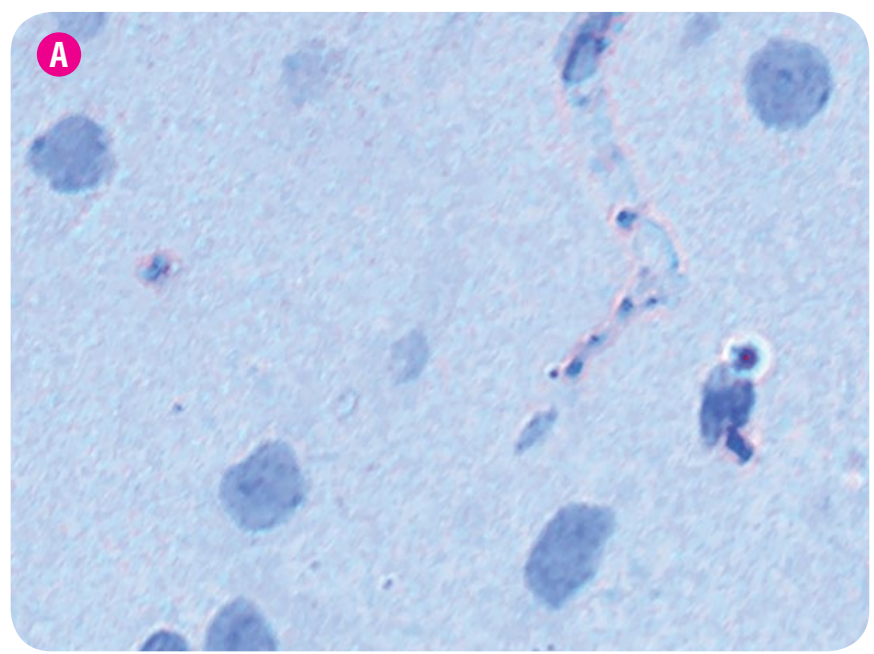

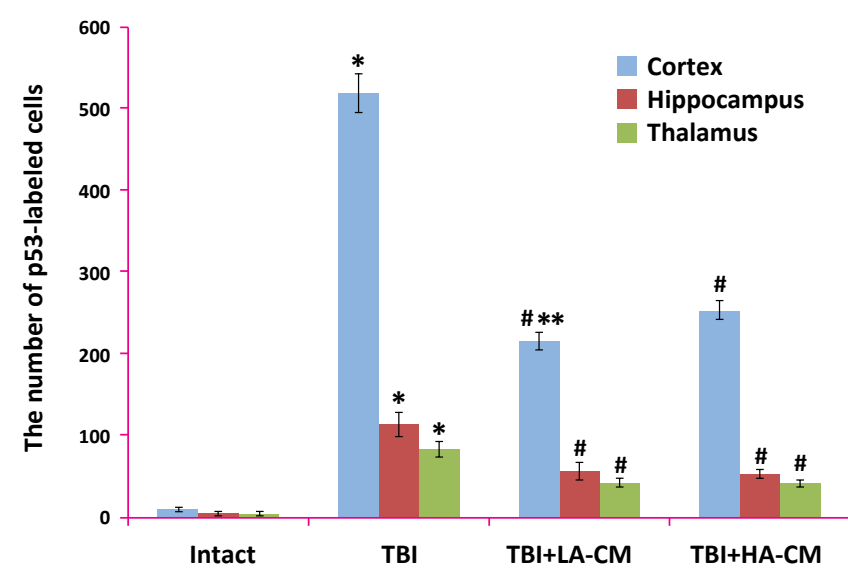

A Fig. 2. The number of p53-labeled cells per 5 fields of view in the frontal sections of the rat brain (Mean $\pm \mathrm{SEM} ; \mathrm{n}=23$ ). Note: * $-p<0.005$ compared to the group of intact animals, $\#-p<0.05$ compared to the group of TBI animals, * ${ }^{*}-p<0.05$ compared to the group TBI+HA-CM.

cells in the cortex, hippocampus and thalamus by about half compared with the TBI group. The number of p53-positive cells in animals from group TBI+LA-CM in the cortex was $214.6 \pm 7.2$, in the hippocampus $56.2 \pm 3.3$, in the thalamus $41.2 \pm 2.4$ cells, which is likely lower compared with the TBI group $(p<0.05)$. In the cortex of rats from group $\mathrm{TBI}+\mathrm{HA}-\mathrm{CM}$ we found $252.4 \pm 6.3$ p53-positive cells, in the hippocampus $52.5 \pm 3.2$, in the thalamus $40.6 \pm 2.3$ ones (Fig. 2).

It is known that one of the functions of p53 protein is the induction of apoptosis [18]. Therefore, in our study it was important to investigate the effect of traumatic brain injury on apoptosis in different parts of the brain (cortex, hippocampus and thalamus), as apoptosis of CNS cells depends on the area of injury, severity of injury and timing of research $[10,12,13]$. It is also important to establish a possible treatment effect of LA-CM or HA-CM on the development of cell apoptosis in the brain of animals with experimental traumatic brain injury. To analyze the effect of the severity of $\mathrm{TBI}$ and the depth of the penetration of brain damage, which can cause apoptosis of neural cells, the cortex and some subcortical structures (hippocampus and thalamus) were studied.

The obtained results suggest, firstly, that the manifestations of apoptosis of neurons and other brain cells after traumatic brain injury in rats persist for a long time, which coincides with the above literature data [10].

Secondly, the largest number of apoptotic cells was observed in the cerebral cortex. This may indicate that the cortex is the most vulnerable

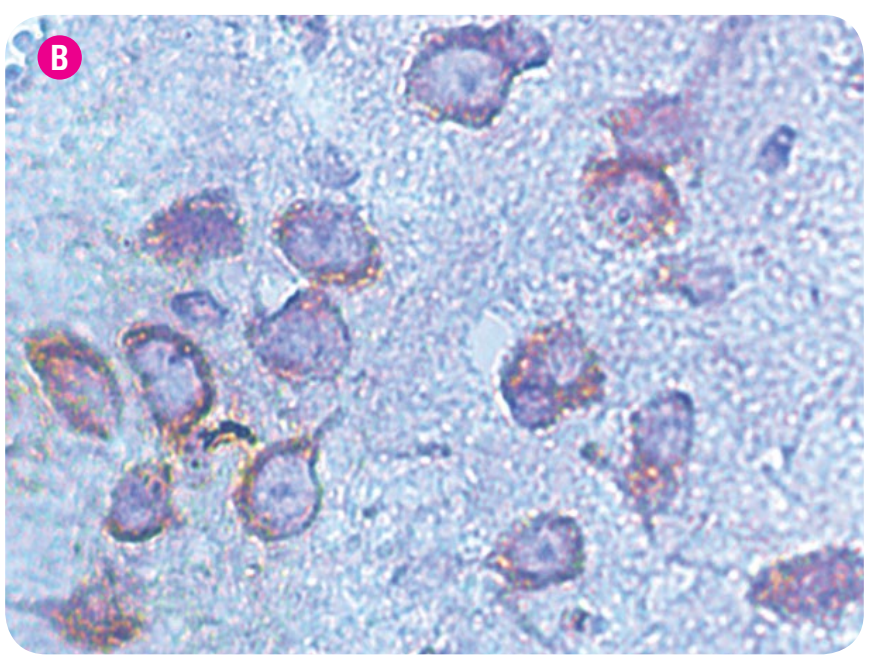

Fig. 3. Photomicrograph of p53-positive cells in the cerebral cortex of an intact rat $(\mathbf{A})$ and a rat on the $5^{\text {th }}$ day after traumatic brain injury $(\mathbf{B})$. Immunohistochemical staining of cell cytoplasm for p53 (brown color); light microscopy, x800. 
to trauma, as it perceives the greatest mechanical damage in injuries to the rat's head.

Thirdly, apoptotic p53-positive cells in the cerebral cortex had a specific brown color mainly in the cytoplasm, not the cell nuclei (Fig. 3). This coincides with the identification of apoptotic brain cells by TUNNEL a method where apoptotic neural cells after trauma are divided into 2 groups of cells. The first group of cells has intense staining of the nucleus only and signs of nuclear fragmentation, and the second - mainly staining of the cytoplasm without fragmentation and staining of the nucleus [9, 11]. The reasons for such manifestations of neural cell apoptosis after trauma are not fully understood. It can be assumed that these are different stages of one process: first p53 protein as a transcription factor is in the nucleus, and then moves to the cytoplasm, where it interacts, for example, with mitochondria and leads to the release of cytochrome $\mathrm{C}$ mitochondria and induces irreversible neuronal apoptosis [8, 9].

The use of two different conditioned media from fetal brain cell cultures cultured in serum-depleted nutrient medium, had an inhibitory effect on the manifestations of apoptosis after traumatic brain injury in rats. Thus, three injections of LA-CM or HA-CM on the $2^{\text {nd }}, 3^{\text {rd }}$ and $4^{\text {th }}$ days after $\mathrm{TBI}$, which was directed to the secondary inflammation in the TBI pathogenesis, which develops $2-5$ days after the injury $[6,15]$.

Comparing the effects of both conditioned media on apoptosis after $\mathrm{TBI}$, there should be noted approximately the same effect on both the cortex and subcortical structures of the brain. Decrease the number of p53-positive cells on the $5^{\text {th }}$ day after trauma due to administration of conditioned media suggests that apoptosis of neural cells after injury has a gradually increasing dynamic. Under certain conditions we can stop this process or block effects of the various apoptotic factors on the neural cells or, conversely, we can stimulate the reparation and recovery of damaged cells $[10,12,14]$. Further research can provide a final answer to these questions.

Conditioned media obtained from fetal brain cell cultures with different adhesive properties contain some factors that inhibit the development of apoptosis in brain cells, but do not completely block it. Inhibitory effect on apoptosis of neural cell has been observed in the cortex and subcortical structures of the brain, which may indicate that both high-adhesive and low-adhesive neural cells are able to produce anti-apoptotic trophic factors. The data obtained coincide with the results of other authors, which showed that the biological activity of trophic factors produced by stem cells in cell culture corresponded to the effects of cell transplantation after injury $[2,3,14]$. The mechanism of impact of conditioned media on apoptosis in brain cells can be both direct and indirect through other mediators. It is known that humoral factors secreted by stem cells are able to show anti-inflammatory, reparative, activating and other effects on the brain after trauma, stimulate angiogenesis and proliferation of glial cells $[2,3,5]$. Although both conditioned media significantly reduced the number of p53-positive cells in different brain structures, LA-CM probably inhibited apoptosis of cells in the cerebral cortex more than HA-CM, which may indicate some differences in their activity and composition. It is possible that further study of these humoral factors, which are secreted by cells with different adhesion to plastic, will allow to reveal some of their specific properties and develop therapeutic products for clinical use.

\section{CONCLUSION}

1. Traumatic brain injury in rats is accompanied by a significant increase in the number of p53-positive cells in the cerebral cortex, hippocampus and thalamus on the $5^{\text {th }}$ day after injury, which indicates the development of apoptosis in brain cells after injury.

2. Significantly higher number of p53-positive cells was found in the cerebral cortex than in subcortical structures such as the hippocampus and thalamus, suggesting that apoptosis after TBI prevailed in the cortex than in other brain areas, possibly at the expense of neurons.

3. The administration of conditioned media of fetal brain neural cells after TBI promotes a significant decrease in the number of p53-positive cells in both the cortex and subcortical structures.

4. The anti-apoptotic effects of two conditioned media from high-adhesive and low-adhesive neural cells cultures after brain injury did not differ in hippocampus and thalamus, while in the cortex the anti-apoptotic effect of conditioned media from low-adhesive cultures was higher than from high-adhesive cells. This may indicate the presence of similar biologically active humoral factors in the studied media, as well as certain differences in their composition

\section{REFERENCES:}

1. Wood H. Stem cell implants show promise in chronic traumatic brain injury. Nat Rev Neurol. 2021; 17(2):64. DOl: 10.1038/s41582-021-00459-y.

2. Xiong Y, Mahmood A, Chopp M. Emerging potential of exosomes for treatment of traumatic brain injury. Neural Regen Res. 2017; 12(1):19-22. D0I: 10.4103/16735374.198966 .

3. Jha KA, Gentry J, Del Mar NA, Reiner A, Sohl N, Gangaraju R. Adipose tissue-derived mesenchymal stem cell concentrated conditioned medium alters the expression pattern of glutamate regulatory proteins and aquaporin-4 in the retina after mild traumatic brain injury. J Neurotrauma. 2021. Online ahead of print. DOl: 10.1089/neu.2020.7309.

4. SavelieffMG, FeldmanEL. Traumatic brain injury: a success stemming from stem cells. Neurology. 2021. Online ahead of print. D0l: 10.1212/WNL.0000000000011455.

5. Andrews EM, Tsai SY, Johnson SC, Farrer JR., Wagner JP, Kopen GC, et al. Human adult bone marrow-derived somatic cell therapy results in functional recovery and axonal plasticity following stroke in the rat. Exp Neurol. 2008; 211(2):588-92.

6. Wong J, Hoe NW, Zhiwei F, Ng I. Apoptosis and traumatic brain injury. Neurocrit Care. 2005; 3(2):177-82. D0I: 10.1385/NCC:3:2:177.

7. Glushakova OY, Glushakov AO, Borlongan CV, Valadka AB, Hayes RL, Glushakov AV. Role of caspase-3-mediated apoptosis in chronic caspase-3-cleaved tau accumulation and blood-brain barrier damage in the corpus callosum after traumatic brain injury in rats. J Neurotrauma. 2018; 35(1):157-73. D0l: 10.1089/ neu.2017.4999.

8. Sullivan PG, Keller JN, Bussen WL, Scheff SW. Cytochrome C release and caspase activation after traumatic brain injury. Brain Res. 2002; 949(1-2):88-96. D0I: 10.1016/s0006-8993(02)02968-2.

9. Shao X, Yang X, Shen J, Chen S, Jiang X, Wang Q, et al. TNF-alpha-induced p53 activation induces apoptosis in neurological injury. J Cell Mol Med. 2020; 24(12):6796-803. DOI: 10.1111/jcmm.15333.

10. Conti AC, Raghupathi R, Trojanowski JQ, McIntosh TK. Experimental brain injury induces regionally distinct apoptosis during the acute and delayed post-traumatic period. J Neurosci. 1998; 18(15):5663-72. DOI: 10.1523/JNEUROSCI.18-15-05663.1998. 
11. Maor-Nof M, Shipony Z, Lopez-Gonzalez R, Nakayama L, Zhang YJ, Couthouis J, et al. p53 is a central regulator driving neurodegeneration caused by C9orf72 poly(PR). Cell. 2021; 184(3):689-708.e20. DOI: 10.1016/j.cell.2020.12.025.

12. Huang $Y N$, Yang $L Y$, Greig NH, Wang $Y C$, Lai $C C$, Wang $J Y$. Neuroprotective effects of pifithrin-a against traumatic brain injury in the striatum through suppression of neuroinflammation, oxidative stress, autophagy, and apoptosis. Sci Rep. 2018; 8:2368. DOl:org/10.1038/s41598-018-19654-X.

13. Yang $L Y$, Greig NH, Tweedie D, Jung YJ, Chiang YH, Barry J, et al. The p53 inactivators pifithrin- $\mu$ and pifithrin-a mitigate TBI-induced neuronal damage through regulation of oxidative stress, neuroinflammation, autophagy and mitophagy. Exp Neurol. 2020; 324:113135. D0l: 10.1016/j.expneurol.2019.113135.

14. Zhang Y, Chopp M, Zhang ZG, Katakowski M, Xin H, Qu C, et al. Systemic administration of cell-free exosomes generated by human bone marrow derived mesenchymal stem cells cultured under 2D and 3D conditions improves functional recovery in rats after traumatic brain injury. Neurochem Int. 2016; 111:69-81. DOI: 10.1016/..neuint.2016.08.003.

15. Romanova GA, Shakova FM, Parfenov AL. Modelirovanie cherepno-mozgovoy travmy. [Modeling of traumatic brain injury]. Patofiziologicheskaya fiziologiya i eksperimental'naya terapiya - Pathophysiological physiology and experimental therapy. 2015; 59(2):112-5. [In Russian]

16. Beloshitskiy VV. Printsipy modelirovaniya cherepno-mozgovoy travmy v eksperimente. [Principles of modeling traumatic brain injury in experiment]. Ukr neyrokhirurg zhur -Ukrainian Neurosurgical Journal. 2008; 4:9-15. [In Russian]

17. Zozulya YuA, Lisyany NI, Tsymbalyuk VI, Semenova VM, Lyubich LD. Neyrogennaya differentsirovka stvolovykh kletok [Neurogenic stem cell differentiation]. Kiev, 2005. 365 p. [In Russian]

18. Aubrey BJ, Kelly GL, Janic A, Herold MJ, Strasser A. How does p53 induce apoptosis and how does this relate to p53-mediated tumour suppression? Cell Death Differ. 2018; 25:104-13. DOI: 10.1038/cdd.2017.169.

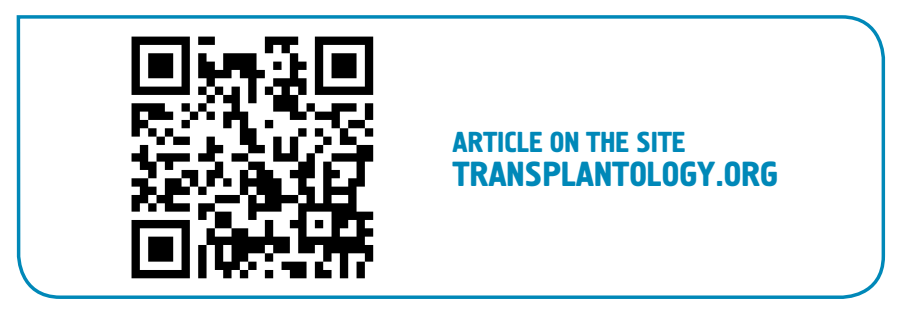

The authors declared no potential conflicts of interest with respect to the research, authorship, and/or publication of this article. 


\section{Вплив кондиційного середовища культур фетальних нервових клітин на апоптотичні процеси в головному мозку щурів після черепно-мозкової травми}

Лісяний М. І. ${ }^{1}$, Говбах I. О. ${ }^{2}$, Бельська Л. М. ${ }^{1}$, Цупиков О. ${ }^{3,4}$, Паламарьова А. В. ${ }^{1}$

${ }^{1}$ ДУ «Інститут нейрохірургії ім. акад. А. П. Ромоданова НАМН України», Київ, Украйна

${ }^{2}$ Харківська медична академія післядипломної освіти МОЗ України, Харків, Україна

${ }^{3}$ Інститут фізіології ім. О. О. Богомольия Національної академії наук України, Київ, Україна

${ }^{4}$ ДУ «Інститут генетичної та регенеративної медицини Національної академії медичних наук України», Київ, Україна

\section{PEЗЮME}

Перспективним методом лікування наслідків ЧМТ може стати клітинна терапія з використанням стовбурових клітин. Проте відкритим залишається питання щодо природи, умов отримання та механізмів дії гуморальних чинників стовбурових клітин на апоптотичні та репаративні процеси в мозку після ЧМТ.

МЕТОЮ РОБОти було вивчення впливу кондиційних середовищ культур фетальних нейральних клітин на розвиток апоптозу в корі та підкоркових структурах головного мозку щурів після ЧМТ.

MATEPIAЛИ ТА МЕТОДИ. Черепно-мозкову травму моделювали шляхом падіння металевого циліндра на голову щура. Для отримання культур нейральних стовбурових/прогеніторних клітин використовували плоди щурів (E17-18). Кондиційні середовища 3 культур клітин з високими адгезивними властивостями (КС-ВА) та низькими адгезивними властивостями (КС-НА) були використані для лікування наслідків експериментальної ЧМТ щурів. Вплив кондиційних середовищ на розвиток апоптозу в корі та підкоркових структурах головного мозку після ЧМТ досліджували за допомогою імуногістохімічного аналізу з використанням антитіл проти білка р53.

РЕЗУЛЬТАТИ. Імуногістохімічний аналіз зрізів головного мозку показав, що на 5-у добу після ЧМТ головного мозку в щурів спостерігалося збільшення кількості р53-мічених клітин як у корі, так і підкоркових структурах головного мозку. Введення КС-НА і КС-ВА тваринам на 2-у, 3-ю, 4-у добу після ЧМТ зменшувало кількість р53-позитивних клітин у корі, гіпокампі та таламусі приблизно вдвічі порівняно із групою ЧМТ. Не було виявлено вірогідної різниці в гальмівній дії двох різних кондиційних середовищ від культур з високими та низькими адгезивними властивостями на апоптичні процеси в головному мозку щурів після ЧМТ.

ВИСновки. Введення кондиційних середовищ культур нервових клітин плоду щурів викликало значне зменшення кількості р53позитивних клітин як в корі, так і в підкіркових структурах на 5-ту добу після черепно-мозкової травми.

ключові словА: черепно-мозкова травма; фретальні нервові клітини; кондиційне середовище; апоптоз; р53 